\title{
The impact of COVID-19 and control measures on public health in Thailand, 2020
}

\author{
Ritthideach Yorsaeng ${ }^{1}$, Nungruthai Suntronwong ${ }^{1}$, Ilada Thongpan ${ }^{1}$, Watchaporn Chuchaona ${ }^{1}$, Fajar Budi Lestari \\ ${ }^{1}$, Siripat Pasittungkul ${ }^{1}$, Jiratchaya Puenpa ${ }^{1}$, Kamolthip Atsawawaranunt ${ }^{2,3}$, Chollasap Sharma ${ }^{3,4}$, Natthinee \\ Sudhinaraset $^{1}$, Anek Mungaomklang ${ }^{2}$, Rungrueng Kitphati ${ }^{5}$, Nasamon Wanlapakorn ${ }^{1}$, Yong Poovorawan ${ }^{\text {Corresp. } 1}$ \\ 1 Department of Pediatrics, Faculty of Medicine, Chulalongkorn University, Center of Excellence in Clinical Virology, Pathumwan, Thailand \\ Department of Disease Control, Ministry of Public Health, Institute for Urban Disease Control and Prevention, Bangkok, Thailand \\ 3 Department of Disease Control, Ministry of Public Health, Institute of Preventive Medicine, Nonthaburi, Thailand \\ 4 Department of Disease Control, Ministry of Public Health, Division of International Disease Control Port, Nonthaburi, Thailand \\ 5 Ministry of Public Health, Nonthaburi, Thailand \\ Corresponding Author: Yong Poovorawan \\ Email address: Yong.P@chula.ac.th
}

Background: The COVID-19 virus has been causing an emerging disease with global outbreaks for over a year. In Thailand, transmission could be controlled by strict measures that could positively and negatively impact physical health and suicidal behavior.

Methods: The COVID-19 incidence was retrieved from the Department of Disease Control (DDC). The impact of viral diseases was retrieved from the open-source of the DDC, and King Chulalongkorn Memorial Hospital. The road accidents data were from the Thai Ministry of Transport. The suicidal behavior data were obtained from the Department of Mental Health. We compared data from the year 2019 with the pandemic COVID-19 outbreak period in 2020, before lockdown, during lockdown, easing, and new wave period using unpaired t-test and least-squares linear regression. We compared the impact of the outbreak on various data records in 2020 with corresponding non-outbreak from 2019.

Results: There was a significant decline in cases of influenza $(p<0.001)$ and norovirus $(p=0.01)$. However, there was no significant difference in RSV cases $(p=0.17)$. There was a dramatic increase in attempt to suicides and suicides $(p<0.001)$. There was no impact on roadside accidents and outpatient department visits.

Discussion: The extensive intervention measures during lockdown during the first wave positively impacted total cases for each period for acute respiratory and gastrointestinal tract diseases, car accidents, and injuries and negatively impacted indicators of suicidal behavior. The data support government policies that would be effective against the next outbreak by promoting the "new normal" lifestyle. 


\section{The impact of COVID-19 and control measures on public}

\section{2 health in Thailand, 2020}

3

4

5

6

7

8

Ritthideach Yorsaeng ${ }^{1}$, Nungruthai Suntronwong ${ }^{1}$, Ilada Thongpan ${ }^{1}$, Watchaporn Chuchaona ${ }^{1}$, Fajar Budi Lestari ${ }^{1}$, Siripat Pasittungkul ${ }^{1}$, Jiratchaya Puenpa ${ }^{1}$, Kamolthip Atsawawaranunt ${ }^{2,4}$, Chollasap Sharma ${ }^{3,4}$, Natthinee Sudhinaraset ${ }^{1}$, Anek Mungaomklang ${ }^{2}$, Rungrueng Kitphati ${ }^{5}$, Nasamon Wanlapakorn ${ }^{1}$, Yong Poovorawan ${ }^{1 *}$

${ }^{1}$ Center of Excellence in Clinical Virology, Department of Pediatrics, Faculty of Medicine, Chulalongkorn University, Pathumwan, Thailand

${ }^{2}$ Institute for Urban Disease Control and Prevention, Department of Disease Control, Ministry of Public Health, Bangkok, Thailand

${ }^{3}$ Division of International Disease Control Port, Department of Disease Control, Ministry of Public Health, Nonthaburi, Thailand ${ }^{4}$ Institute of Preventive Medicine, Department of Disease Control, Ministry of Public Health, Nonthaburi, Thailand

${ }^{5}$ Ministry of Public Health, Nonthaburi, Thailand

Corresponding Author:

Yong Poovorawan

Center of Excellence in Clinical Virology, Department of Pediatrics, Faculty of Medicine, Chulalongkorn University, Pathumwan, 10330, Thailand

Email address: yong.p@chula.ac.th

\section{Abstract}

Background: The COVID-19 virus has been causing an emerging disease with global outbreaks for over a year. In Thailand, transmission could be controlled by strict measures that could positively and negatively impact physical health and suicidal behavior.

Methods: The COVID-19 incidence was retrieved from the Department of Disease Control (DDC). The impact of viral diseases was retrieved from the open-source of the DDC, and King Chulalongkorn Memorial Hospital. The road accidents data were from the Thai Ministry of Transport. The suicidal behavior data were obtained from the Department of Mental Health. We compared data from the year 2019 with the pandemic COVID-19 outbreak period in 2020, before lockdown, during lockdown, easing, and new wave period using unpaired t-test and leastsquares linear regression. We compared the impact of the outbreak on various data records in 2020 with corresponding non-outbreak from 2019.

Results: There was a significant decline in cases of influenza $(p<0.001)$ and norovirus $(p$ $=0.01)$. However, there was no significant difference in RSV cases $(p=0.17)$. There was a 
40 dramatic increase in attempt to suicides and suicides $(p<0.001)$. There was no impact on

41 roadside accidents and outpatient department visits.

42 Discussion: The extensive intervention measures during lockdown during the first wave 43 positively impacted total cases for each period for acute respiratory and gastrointestinal tract 44 diseases, car accidents, and injuries and negatively impacted indicators of suicidal behavior. The 45 data support government policies that would be effective against the next outbreak by promoting 46 the "new normal" lifestyle.

47

48

49

50

51

52

53

54

55

56

57

58

59

60

61

62

63

64

65

66

67

68

69

70

71

72

73

74

75

76

77

78

79

\section{Introduction}

The coronavirus disease 2019 (COVID-19 pandemic) is a recently emerging infectious disease. The first outbreak was found in Wuhan, Hubei, mainland China in December 2019. The World Health Organization (WHO) declared a Public Health Emergency of International Concern (PHEIC) on January, 302020 and a pandemic on March 11, 2020 (World Health Organization, 2020).

\section{Early 2020}

The Thai Department of Disease Control (DDC) began screening direct flight passengers from Wuhan on January 3 by a Thermoscan device at the airport (Hinjoy etal., 2020) and sent a suspected case to quarantine. A traveler from Wuhan with fever on January 8, confirmed by RTPCR on January 12 and with official reported SARS-CoV-2 infection on January 13 (Emergency Operation Center, 2020; World Health Organization, 2020) had the first COVID-19 case reported outside mainland China (Okada et al., 2020). The first domestic case was found on January 31, a taxi driver who drove a foreign passenger (Pongpirul et al., 2020). Fifty confirmed cases of COVID-19 were reported from January 13 - March 9, most of which were foreign travelers. In early 2020, a Thai group from a high-risk area was placed in isolation and under observation for 14 days called "State Quarantine" (SQ) (Limsawart et al., 2020; Department of Disease Control, 2020) with Government subsidized the expense. The first confirmed SQ case occurred on February 8, in a Thai returning from Wuhan (Department of Disease Control, 2020).

The Thai DDC activated the Emergency Operation Center (EOC) on January 4, then officially declared COVID-19 a dangerous communicable disease on February 29. So, the government used intensive measures to limit the outbreak through legislation (Limsawart et al., 2020).

During this period, hygiene was promoted through social distancing, hand sanitization, and wearing a facemask. Supplies of alcohol-based sanitizers and surgical masks, however, were insufficient. The Thai Department of Health recommended February 14 that people wear a fabric facemask (Bureau of Information Office of the Permanent Secretary, 2020). The government then allowed the alcohol industry to increase alcohol production for direct retail sanitizer sale (MGR Online, 2020).

Although Thailand responded well to an early outbreak, there was concern about transmission in two clusters: 1) entertainment venues and 2) the boxing stadium. The largest outbreak traced to the boxing stadium occurred on March 6, with over 4,500 participants from 
80

81

82

83

84

85

86

87

88

89

90

91

92

93

94

95

96

97

98

99

100

101

102

103

104

105

106

107

108

109

110

111

112

113

114

115

116

117

118

around the country. After these clusters, domestic cases increased enormously, with the highest peak of 188 patients on March 18, and daily new cases numbered over 100 per day on week 1215. Participants returned to their hometowns after Bangkok's lockdown on March 22 and thus spread the disease nationwide (Triukose et al., 2021).

\section{Tightened measures}

Nationwide outbreak situation led to the imposition of measures that could reduce the transmission as shown in the Figure S1 (Figure S1). In addition, the government suspended international flights and allowed only Thai and foreigners who worked or resided in Thailand to return with strict requirements: COVID-19-free medical certificate within 72 hours before a flight, certificate of entry (COE), and fit-to-fly health certificate from the Thai Royal Embassy or Consulate before boarding, and health insurance for foreigners. They were detained in SQ for 14 days beginning April 4 (Limsawart et al, 2020; Department of Disease Control, 2020; Office of the Permanent Secretary for Interior, Ministry of Interior, 2020).

After these interventions, daily confirmed new cases substantially decreased. The last domestic case was reported on May 25. After that, there was no local transmission. The reported new COVID-19 cases were from the SQ only (Department of Disease Control, 2020).

\section{Easing}

For successful disease control, the government implemented easing measures in five phases (Triukose et al., 2021; Department of Disease Control, 2020).

The first easing on May 3 allowed reopening of fresh markets, food and beverage shops outside department stores, barbers, outdoor exercise facilities except for group activities, and pet shops, and canceled alcoholic beverage trade prohibitions.

The second easing on May 17 allowed reopening of shopping centers except for cinemas, bowling alleys, and amusement parks; hotel meeting rooms with limited participants; beauty clinics; only fitness centers outside department stores; indoor stadiums with three persons per one team; public parks; museums; learning centers; libraries; and galleries and shortened the curfew period (23:00-04:00).

The third easing on June 1 allowed group dining out with maintaining at least 1-meter social distance and full service for shopping centers, barbers, beauty clinics, spas, traditional massage parlors, tattoo parlors, body-piercing shops, fitness clubs, cinemas, exhibition venues, and child daycare centers if they followed the CCSA recommendations, and reopened zoos and allowed group sports for practice only and boxing without a trainer.

The fourth easing on June 15 allowed reopening tutorial schools with appropriate hygiene measures and distanced seating; serving alcohol in restaurants except for pubs, bars, and karaoke shops; seating passengers next to each other; reopening saunas; and allowing competition sports without spectators.

The fifth easing on July 1 allowed businesses such as pubs, bars, karaoke venues, gaming centers, internet cafes, and soapy massage parlors to reopen and close before midnight. Public vehicles were allowed to carry passengers at $70 \%$ of capacity because of schools 
119 reopening (Limsawart et al, 2020; Department of Disease Control, 2020; Office of the Permanent 120 Secretary for Interior, Ministry of Interior, 2020).

121 The first wave results

122 Thailand is the few countries that completely controlled disease transmission in the first

123 wave. Domestic cases no longer occurred by 100 days after the last case on May 25. A new

124 domestic case occurred on September 4 of unknown origin. In this case, the patient worked in

125 entertainment venues and was incarcerated in the penitentiary at the time the disease was

126 detected. No close contacts of the patient had positive PCR results (Department of Disease

127 Control, 2020; Office of the Permanent Secretary for Interior, Ministry of Interior, 2020).

128 In the last trimester of 2020, neighborhoods around Thailand confronted a high incidence

129 of COVID-19, and a problem remained on borders because of smuggling immigrants entering

130 Thailand to look for a job. Thailand dealt with this situation by concentrating border patrol

131 police, armed forces patrols, and health volunteers on the border and focused checkpoints along

132 the road in these areas. Illegal foreign immigrants were sent back to their country of origin. Thai

133 workers illegally entering Thailand were sent to local quarantine, another type of SQ

134 (Department of Disease Control, 2020; Office of the Permanent Secretary for Interior, Ministry

135 of Interior, 2020).

136 Thailand has strengthened surveillance along borders. Some immigrants could otherwise

137 enter Thailand without being arrested, leading to a new cluster. On November 26, the first

138 confirmed case in this cluster occurred in a Thai worker in 1G1-7 hotel-cum-entertainment

139 complex, Tachilek, Myanmar. After the first case was found on November 26, the number of

140 new infections linked to the 1G1-7 hotel had risen to over 10 Thai workers who illegally entered

141 to Thailand via natural borders. This cluster could spread the disease to two indigenous Thai

142 (Department of Disease Control, 2020; Office of the Permanent Secretary for Interior, Ministry

143 of Interior, 2020).

144 The new wave

145

146

147

148

149

Although Thailand could control previous clusters, smuggling immigrants into Thailand led to the new wave in December 2020. A new wave from the Central Shrimp Market, Samut Sakhon Province on December 17. This cluster was related to Myanmar workers who smuggle immigrants to Thailand, and they live in crowded conditions with poor hygiene. After this, active case finding in Myanmar workers found 1,390 cases until the end of 2020. Other clusters

150 occurred at that time in big bike groups, entertainment venues, restaurants, and illegal gambling dens. The illegal gambling den cluster that occurred in Eastern Thailand was difficult to control

152 because gamblers conceal their timeline information. This cluster had over 300 cases and

153

154 remains untraceable to all gamblers. This new wave caused 1,110 confirmed cases in medical

155 facilities and spread disease over 50 provinces within a few days (Department of Disease Control, 2020; Office of the Permanent Secretary for Interior, Ministry of Interior, 2020).

During the new wave, nationwide lockdown was not used but the country was classified into four zones: red, orange, yellow, and green according to the number of reported cases. The zone classification was announced on December 24 (Department of Disease Control, 2020). 
159

160

161

162

163

164

165

166

167

168

169

170

171

172

173

174

175

176

177

178

179

180

181

182

183

184

185

186

187

188

189

190

191

192

193

194

195

196

197

198

In the early wave, Samut Sakhon was defined as a red zone. Neighborhoods (Bangkok, Nakhon Pathom, Samut Songkram, Ratchaburi) and those with a high incidence were defined as orange zones. Provinces with sporadic cases were defined as yellow zones. Any other was defined as a green zone. However, red and orange zones were extended to many provinces, and other regions became yellow zones to counter this situation (Office of the Permanent Secretary for Interior, 2020).

\section{Summary of cases}

On December 31, 2020, there were 6,884 confirmed cases in Thailand with 61 deaths (mortality $0.89 \%$ ). In contrast, worldwide confirmed cases exceeded 81 million with a total case fatality of approximately 1.8 million (mortality 2.21\%) (Department of Disease Control, 2020; Center for Systems Science and Engineering, 2020). The outbreak and events in 2020 involved the pandemic shown in Fig. 1 and Table 1.

Previous studies revealed that the COVID-19 pandemic was associated with a decrease in incidence of respiratory tract and gastrointestinal tract infections (Lee et al., 2020; Suntronwong et al., 2020; Wong et al., 2020). However, these studies were conducted during the pre- and early-pandemic period (January - early April 2020). Long-term data on the dynamic changes of incidence rates were limited, especially when different measurements for controlling the COVID-19 were implemented.

Our study aimed to reveal the impact of COVID-19 control measures on incidence of other viral infections and effects on suicidal behavior, accidents, and outpatient department (OPD) visits between 2019 and 2020. Positive and negative effects were compared with the previous data before the outbreak. The results could help health policymakers prepare for measures to reduce adverse events from interventions to contain a contagious disease.

\section{Materials \& Methods}

We assessed and compared the data records on acute viral respiratory tract and gastrointestinal tract infections, OPD visits, road accidents, and suicidal behavior in Thailand during the COVID-19 period vs. the analogous period in 2019. This study used secondary anonymous information and did not require ethical approval.

Data sources

This study used Government agency statistics. The COVID-19 data were retrieved from the Thai DDC (Department of Disease Control, 2020). Data on the incidence of respiratory tract and gastrointestinal infections were from clinical records from the hospital in Bangkok (Suntronwong et al., 2020). Data on the incidence of vector-borne infection were from Report 506 (Bureau of Epidemiology, 2021). OPD visits data were retrieved directly from King Chulalongkorn Memorial Hospital (KCMH). Suicidal behavior (attempt to suicide and suicide) data were retrieved from the self-harm surveillance system (Report 506S) of the Thai Department of Mental Health (Department of Mental Health, 2021). The accident data were retrieved from the TRansport Accident Management Systems (TRAMS) report system of the Thai Ministry of Transport (Ministry of Transport, 2021). Data were from the period January 1 to December 31, 
199

200

201

202

203

204

205

206

207

208

209

210

211

212

213

214

215

216

217

218

219

220

221

222

223

224

225

226

227

228

229

230

231

232

233

234

235

236

237

238

2020. Control data were those before COVID-19 emerged and compared an event, holiday, and festival for the same time period in 2019. The unpaired t-test and least-squares linear regression were used to compare total cases each year and each period [Before lockdown (week 1-11), Lockdown (week 12-18), Easing (week 19-50), and New wave (week 51-53)]. Bonferroni correction was used to corrected $p$ value thresholds in each period, $p$ value $<0.05$ for total cases in each year, and $<0.0125$ for each period were considered statistically significant.

\section{Results}

This study provides data about other viral diseases, suicidal behavior, OPD visits, and traffic situations in the COVID-19 era.

\section{Impact on other viral infections}

There was a significant reduction in total influenza cases in 2020 as compared to 2019 (Fig. 2a) as shown in Table 2. There was a positive impact on reduction of influenza cases in 2020 during lockdown and easing. The total number of cases of respiratory syncytial virus (RSV) in 2019 compared to 2020 (Fig. 2b) was not significantly different, as shown in Table 2.

Total cases of rotavirus were significantly higher in 2020 compared to 2019 (Fig. 2c), as shown in Table 2, but rotavirus cases in 2020 declined after lockdown. After an initial spike in early 2020, norovirus total cases in 2020 were significantly less compared to 2019 (Fig. 2d), as shown in Table 2. There was a positive impact on reducing norovirus cases in 2020 during the easing and new-wave periods.

Dengue total cases in 2020 compared to 2019 (Fig. 2e) were significantly reduced, as shown in Table 2. However, data in 2020 during the new wave period were not available for analysis.

\section{Impact on outpatient department}

There were no significant differences in patient visits to the OPD service in the KCMH in 2019 compared to 2020 (Fig. 3), as shown in Table 3. Although overall patient visits were not significantly different, there was a declining trend during the lockdown.

\section{Impact on suicidal behavior}

The suicidal behavior data focused on two outcomes, attempt to suicides and suicides. Attempt to suicide cases significantly increased in 2020 compared to 2019 (Fig. 4a) as shown in Table 4. Suicide total cases in 2020 significantly increased compared to 2019 (Fig. 4b) as shown in Table 4. Attempt to suicides and suicides increased in 2020 before and during lockdown and decreased during easing.

\section{Impact on Road accident incidences and fatalities}

Indicators of the road accidents in Thailand were car accidents, injuries from road accidents, and fatalities from road accidents from TRAMS data in 2019 compared to 2020. Road accidents (Fig. 5a), injuries from road accidents (Fig. 5b), and fatalities from road accidents (Fig. 
239

240

241

\section{Discussion}

243

244

245

246

247

248

249

250

251

252

253

254

255

256

257

258

259

260

261

262

263

264

265

266

267

268

269

270

271

272

273

274

275

276

277

278 avoidance.

5c) were not significantly different during the 2020, as shown in Table 5. These cases tended to increase in 2020 during easing but declined somewhat during lockdown.

The COVID-19 pandemic and interventions have led to changes in human lifestyles with people becoming accustomed to a "new normal". This study focused on the impact in Thailand on various aspects, including public health, suicidal behavior, socioeconomics, and road accidents. Both positive and negative effects were found when comparing pandemic and prepandemic periods.

Because of improved personal hygiene, including hand washing and alcohol-based sanitization (Gupta \& Lipner, 2020), facemask use (Liang et al., 2020), and social distancing, viral upper respiratory tract and viral gastrointestinal tract infections significantly decreased. Although rotavirus significantly increased prior to lockdown during early 2020, there were only six cases during the lockdown, and no more after that.

A vector-borne viral disease, dengue, was significantly reduced in this analysis as a result of the pandemic. National data surveillance (Bureau of Epidemiology, 2021) revealed that dengue has been outbreaking out every 2-3 years. The year 2020 was not an outbreak year in Thailand's outbreak pattern. Of communicable diseases generally spread through the community, especially in the urban or crowded areas, the interventions focusing on a lockdown and travel restrictions can limit disease spread.

As COVID-19 spreads, the total number of patients in the OPD decreased during the nationwide outbreak in many hospitals, including KCMH. Some hospitals limited the number of daily patients and required appointments for non-emergency cases. Moreover, an online service was used to reduce the number of outpatients in hospitals by drug deliveries and telemedicine consultation. Patients also had access to a small clinic instead of the hospital to disease

Mental health during the pandemic is as significant a problem as physical health. Various factors associated with mental health included misinformation, lack of knowledge, socioeconomic problems, social media use, and isolation/quarantine issues. The systematic review showed significantly increased depression, fear, anxiety, stress, suicidal behavior, job loss, financial crisis, nutrition disorders and increase work load in medical personnel (B C et al., 2021; Gao et al., 2020; Goodwin et al., 2020; John et al., 2021; Salari et al., 2020). These factors could lead to self-harm or suicidal behavior. The trend of suicide during the early month of the COVID-19 pandemic increase (Parkis et al., 2021), however, each country has different situation, measurement, people attitude which could affect mental health and suicidal behavior. In Thailand 2020, there was an increase in suicidal behavior including attempts to suicides and suicides.

Certain populations are a higher risk. Continuing treatment for people with pre-existing mental health problems is challenging because of lockdown and travel restrictions. Health care workers are also vulnerable because of increased workload and concern about disease exposure (Nochaiwong et al., 2020). People in SQ have unpleasant experiences being isolated for 2 weeks. 
279 Unemployed people suffered from financial and socioeconomic distress (Blakely, Collings \& 280 Atkinson, 2003). More importantly, people who were cured of COVID-19 have been stigmatized 281 by their community (Roberto, Johnson \& Rauhaus, 2020). There are additional deteriorating 282 economics. The Gross Domestic Product (GDP) in 2020 decreased by $7.1 \%$ (in 2019 it increased

283

284

285

286

287

288

289

290

291

292

293

294

295

296

297

298

299

300

301

302

303

304

305

306

307

308

309

310

311

312

313

314

315

316

317

318 by 2.4\%) (International Monetary Fund. Thailand, 2020).

Generally, Thailand celebrates the Thai New Year (Songkran festival) during the middle of April (April 13-15). In the past several years, the highest number of accidents occurred during this period due to the massive transport out of Bangkok. In 2020, injuries and fatalities from road accidents dramatically decreased during the Songkran festival. The reduction was due to the fact that the Government rescheduled the Songkran festival to July 25-28. Drunk driving has been a major cause of road accidents (Ministry of Transport, 2021). In the middle of April 2020, alcohol trade were prohibited, thus resulting in a reduction of drunk driving and road accidents.

However, the total numbers of road accidents, injuries, and fatalities increased significantly in 2020. During the first easing phase, measures against the outbreak were not strict. People were free to travel without restriction and alcohol trade was permitted, so there were no differences in road accidents in 2020 and 2019.

Limitations of this study included the use of secondary data that did not provide complete information such as age, gender, or other information. Subjects could not be stratified into subgroups for further analysis. Only confirmed cases in the medical facilities were reported to the central MoPH agency. Data from other viral infections (Influenza, RSV, rotavirus, and norovirus) and outpatient department came from only some hospitals around Bangkok because national data on RSV and norovirus are not available, and national data on influenza are from suspected and confirmed cases. Furthermore, lockdown measure could be a confounding variable for the presentation of all events.

\section{Conclusions}

This study assessed the effects of interventions involving the COVID-19 pandemic in Thailand in 2020. Strict measures against the first wave could control the outbreak with substantially reduce morbidity and mortality within a few weeks. Disease impact can also be lessened by adopting a "new normal" lifestyle during the COVID-19 era. However, measures imposed during the first wave led to devastating economic consequences and negative effects on suicidal behavior. This measures during the lockdown of the first wave positively impacted total cases for each period for acute respiratory and gastrointestinal tract diseases, road accidents and fatalities.

\section{Acknowledgements}

We are grateful to the staff of the Center of Excellence in Clinical Virology, Chulalongkorn University, and King Chulalongkorn Memorial Hospital, the Thai Red Cross Society for their technical and administrative assistance. We would like to acknowledge the Department of Information Technology, King Chulalongkorn Memorial Hospital, the Thai Red 
319 Cross Society for provided the data from the hospital. We are appreciative and grateful to the 320 staff and nurses of the Institute of Urban Disease Control and Prevention (IUDC), Department of 321 Disease Control, Ministry of Public Health, Thailand for the support valuable data.

322

323

324

325

326

327

328

329

330

331

332

333

334

335

336

337

338

339

340

341

342

343

344

345

346

347

348

349

350

351

352

353

354

355

356

357

358

359

360

361

362

\section{References}

B C UB, Pokharel S, Munikar S, Wagle CN, Adhikary P, Shahi BB, Thapa C, Bhandari RP, Adhikari B, Thapa K. 2021. Anxiety and depression among people living in quarantine centers during COVID-19 pandemic: A mixed method study from western Nepal. PLoS One 16(7):e0254126 DOI: 10.1371/journal.pone.0254126.

Blakely TA, Collings SC, Atkinson J. 2003. Unemployment and suicide. Evidence for a causal association?. Journal of Epidemiology and Community Health 57(8):594-600 DOI: 10.1136/jech.57.8.594.

Bureau of Epidemiology, Department of Disease Control, MoPH, Thailand. National Disease Surveillance (Report 506). 2021. Available at http://www.boe.moph.go.th/boedb/surdata/index.php (accessed 05 January 2021)

Bureau of Information Office of the Permanent Secretary, Ministry of Public Health, Thailand. COVID-19 bulletin 2020. 2020. Available at https://pr.moph.go.th/?url=pr/detail/2/04/138663 (accessed 14 September 2020)

Center for Systems Science and Engineering (CSSE) at Johns Hopkins University (JHU). COVID-19 Dashboard. 2020. Available at https://coronavirus.jhu.edu/map.html (accessed 13 January 2021)

Department of Disease Control. Corona Virus Disease (COVID-19) 2020. Available at https://ddc.moph.go.th/viralpneumonia/file/im_commands/im_commands12_1.pdf (accessed 28 December 2020)

Department of Disease Control. 2020. Corona Virus Disease (COVID-19) 2020. Available at https://ddc.moph.go.th/viralpneumonia (accessed 05 January 2021)

Department of Disease Control. 2020. Available at https://covid19.th-stat.com/api/open/cases (accessed 05 January 2021)

Department of Disease Control. 2020. Available at https://covid19.th-stat.com/api/open/timeline (accessed 15 January 2021)

Department of Mental Health, MoPH, Thailand. Self-harm surveillance system (Report 506S). 2021. Available at https://506s.dmh.go.th (accessed 30 January 2021)

Emergency Operation Center, Department of Disease Control, Thailand. Novel Coronavirus 2019 Pneumonia News release by Emergency Operation Center, Department of Disease Control. 2020. 
363

364

365

366

367

368

369

370

371

372

373

374

375

376

377

378

379

380

381

382

383

384

385

386

387

388

389

390

391

392

393

394

395

396

397

398

399

400

401

402

403

404

405

406

Available at https://ddc.moph.go.th/viralpneumonia/eng/file/news/news no1 130163.pdf (accessed 1 December 2021)

Gao J, Zheng P, Jia Y, Chen H, Mao Y, Chen S, Wang Y, Fu H, Dai J. 2020. Mental health problems and social media exposure during COVID-19 outbreak. PLoS One 15(4):e0231924 DOI: 10.1371 journal.pone.0231924.

Goodwin R, Wiwattanapantuwong J, Tuicomepee A, Suttiwan P, Watakakosol R. 2020. Anxiety and public responses to covid-19: Early data from Thailand. Journal of Psychiatric Research 129:118-21 DOI: 10.1016/j.jpsychires.2020.06.026.

Gupta MK, Lipner SR. 2020. Hand hygiene in preventing COVID-19 transmission. Cutis 105(5):233-234

Hinjoy S, Tsukayama R, Chuxnum T, Masunglong W, Sidet C, Kleeblumjeak P, Onsai N, Iamsirithaworn S. 2020. Self-assessment of the Thai Department of Disease Control's communication for international response to COVID-19 in the early phase. International Journal of Infectious Diseases 96:205-210 DOI: 10.1016/j.jij.2020.04.042.

International Monetary Fund. Thailand. 2020.

Available at https://www.imf.org/en/Countries/THA (accessed 31 January 2021)

John A, Eyles E, Webb RT, Okolie C, Schmidt L, Arensman E, Hawton K, O'Connor RC, Kapur N, Moran P, O'Neill S, McGuiness LA, Olorisade BK, Dekel D, Macleod-Hall C, Cheng HY, Higgins JPT, Gunnell D. The impact of the COVID-19 pandemic on self-harm and suicidal behaviour: update of living systematic review. F1000Res. 2020 Sep 4;9:1097. doi:

10.12688/f1000research.25522.2.

Lee HH, Lin SH. Effects of COVID-19 Prevention Measures on Other Common Infections, Taiwan. Emerg Infect Dis. 2020 Oct;26(10):2509-2511. doi: 10.3201/eid2610.203193. Epub 2020 Jul 30.

Liang M, Gao L, Cheng C, Zhou Q, Uy JP, Heiner K, Sun C. 2020. Efficacy of face mask in preventing respiratory virus transmission: A systematic review and meta-analysis. Travel Medicine and Infectious Disease 36:101751 DOI: 10.1016/j.tmaid.2020.101751.

Limsawart W, Wisetpholchai B, Suksuth P, Anuphongphat N, Sararum T. 2020. COVID-19 Archive: Coalition, unity, against the crisis (First stage 1 January - 30 June 2020). Bangkok: National Archives of Public Health (NAPH): Society and Health Institute (SHI), Ministry of Public Health, Thailand.

Ministry of Transport, Thailand. Transport Accident Management Systems: TRAMS. 2021. Available at https://trams.mot.go.th (accessed 13 January 2021) 
407

408

409

410

411

412

413

414

415

416

417

418

419

420

421

422

423

424

425

426

427

428

429

430

431

432

433

434

435

436

437

438

439

440

441

442

443

444

445

446

447

448

449

450

MGR Online. 2020. Available at https://mgronline.com/daily/detail/9630000031105 (accessed 11 July 2020)

Nochaiwong S, Ruengorn C, Awiphan R, Ruanta Y, Boonchieng W, Nanta S, Kowatcharakul W, Pumpaisalchai W, Kanjanarat P, Mongkhon P, Thavorn K, Hutton B, Wongpakaran N, Wongpakaran T. 2020. Health Outcomes and Mental Health Care Evaluation Survey Research Group (HOME-Survey). Mental health circumstances among health care workers and general public under the pandemic situation of COVID-19 (HOME-COVID-19). Medicine (Baltimore) 99(26):e20751 DOI: 10.1097/MD.0000000000020751.

Office of the Permanent Secretary for Interior, Ministry of Interior. Center for COVID-19 Situation Administration. 2020. Available at http://www.moicovid.com (accessed 03 January 2021)

Okada P, Buathong R, Phuygun S, Thanadachakul T, Parnmen S, Wongboot W, Waicharoen S, Wacharapluesadee S, Uttayamakul S, Vachiraphan A, Chittaganpitch M, Mekha N, Janejai N, Iamsirithaworn S, Lee RT, Maurer-Stroh S. 2020. Early transmission patterns of coronavirus disease 2019 (COVID-19) in travellers from Wuhan to Thailand, January 2020. Euro Surveill 25(8):2000097 DOI: 10.2807/1560-7917.

Pongpirul WA, Pongpirul K, Ratnarathon AC, Prasithsirikul W. 2020. Journey of a Thai Taxi Driver and Novel Coronavirus. The New England Journal of Medicine 382(11):1067-1068 DOI: 10.1056/NEJMc2001621.

Pirkis J, John A, Shin S, DelPozo-Banos M, Arya V, Analuisa-Aguilar P, Appleby L, Arensman E, Bantjes J, Baran A, Bertolote JM, Borges G, Brečić P, Caine E, Castelpietra G, Chang SS, Colchester D, Crompton D, Curkovic M, Deisenhammer EA, Du C, Dwyer J, Erlangsen A, Faust JS, Fortune S, Garrett A, George D, Gerstner R, Gilissen R, Gould M, Hawton K, Kanter J, Kapur N, Khan M, Kirtley OJ, Knipe D, Kolves K, Leske S, Marahatta K, Mittendorfer-Rutz E, Neznanov N, Niederkrotenthaler T, Nielsen E, Nordentoft M, Oberlerchner H, O'Connor RC, Pearson M, Phillips MR, Platt S, Plener PL, Psota G, Qin P, Radeloff D, Rados C, Reif A, ReifLeonhard C, Rozanov V, Schlang C, Schneider B, Semenova N, Sinyor M, Townsend E, Ueda M, Vijayakumar L, Webb RT, Weerasinghe M, Zalsman G, Gunnell D, Spittal MJ. Suicide trends in the early months of the COVID-19 pandemic: an interrupted time-series analysis of preliminary data from 21 countries. Lancet Psychiatry. 2021 Jul;8(7):579-588. doi:

10.1016/S2215-0366(21)00091-2. Epub 2021 Apr 13. Erratum in: Lancet Psychiatry. 2021 Jun 4;: Erratum in: Lancet Psychiatry. 2021 Nov;8(11):e21.

Roberto KJ, Johnson AF, Rauhaus BM. 2020. Stigmatization and prejudice during the COVID-19 pandemic. Administrative Theory \& Praxis 42(3):364-378 DOI:

10.1080/10841806.2020.1782128.

Salari N, Hosseinian-Far A, Jalali R, Vaisi-Raygani A, Rasoulpoor S, Mohammadi M, Rasoulpoor S, Khaledi-Paveh B. 2020. Prevalence of stress, anxiety, depression among the 
451

452

453

454

455

456

457

458

459

460

461

462

463

464

465

466

467

468

469

470

471

472

473

general population during the COVID-19 pandemic: a systematic review and meta-analysis. Global Health 16(1):57 DOI: 10.1186/s12992-020-00589-w.

Suntronwong N, Thongpan I, Chuchaona W, Budi Lestari F, Vichaiwattana P, Yorsaeng R, Pasittungkul S, Kitphati R, Vongpunsawad S, Poovorawan Y. 2020. Impact of COVID-19 public health interventions on influenza incidence in Thailand. Pathogens and Global Health 114(5):225-227 DOI: 10.1080/20477724.2020.1777803.

Triukose S, Nitinawarat S, Satian P, Somboonsavatdee A, Chotikarn P, Thammasanya T, Wanlapakorn N, Sudhinaraset N, Boonyamalik P, Kakhong B, Poovorawan Y. 2021. Effects of public health interventions on the epidemiological spread during the first wave of the COVID-19 outbreak in Thailand. PLoS One 16(2):e0246274 DOI: 10.1371/journal.pone.0246274.

Wong NS, Leung CC, Lee SS. Abrupt Subsidence of Seasonal Influenza after COVID-19 Outbreak, Hong Kong, China. Emerg Infect Dis. 2020 Nov;26(11):2753-2755. doi: 10.3201/eid2611.200861. Epub 2020 Aug 27. World Health Organization. 2020. Novel Coronavirus - Thailand (ex-China). Available at https://www.who.int/emergencies/diseaseoutbreak-news/item/2020-DON234 (accessed 1 December 2021)

World Health Organization. 2020. WHO Director-General's opening remarks at the media briefing on COVID-19 - 11 March 2020. Available at https://www.who.int/directorgeneral/speeches/detail/who-director-general-s-opening-remarks-at-the-media-briefing-on-covid19 (accessed 09 November 2020) 
Table $\mathbf{1}$ (on next page)

Timeline of the COVID-19 outbreak in Thailand. 
1 Table 1. Timeline of the COVID-19 outbreak in Thailand.

\begin{tabular}{|c|c|c|c|c|}
\hline \multirow{16}{*}{ 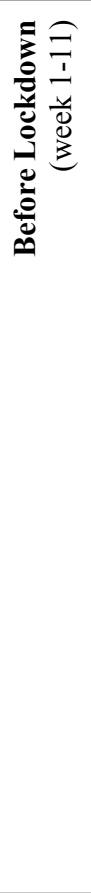 } & Date & Weeks & Event & Detail \\
\hline & January 4 & 1 & Activated EOC & DDC activated the Emergency Operation Center (EOC) \\
\hline & $\begin{array}{l}\text { January } \\
13\end{array}$ & 3 & First confirmed case & First report of COVID-19 case outside mainland China \\
\hline & $\begin{array}{l}\text { January } \\
22\end{array}$ & 4 & EOC upscaled & Thai Prime Minister promoted the EOC to be the Ministerial level \\
\hline & $\begin{array}{l}\text { January } \\
31\end{array}$ & 5 & First domestic case & $\begin{array}{l}\text { First report of COVID-19 in taxi driver who had close contact with a } \\
\text { foreign passenger }\end{array}$ \\
\hline & $\begin{array}{l}\text { February } \\
4\end{array}$ & 6 & Group from Wuhan & $\begin{array}{l}138 \text { Thai nationals return from Wuhan and are sent to state quarantine. } \\
\text { This is the first state quarantine measure that was compulsory for } \\
\text { people coming from an at-risk country }\end{array}$ \\
\hline & $\begin{array}{l}\text { February } \\
8\end{array}$ & 6 & $\begin{array}{l}\text { The first case in state } \\
\text { quarantine }\end{array}$ & $\begin{array}{l}\text { The first case in state quarantine in Thai nationals returning from } \\
\text { Wuhan }\end{array}$ \\
\hline & $\begin{array}{l}\text { February } \\
29\end{array}$ & 9 & $\begin{array}{l}\text { Declared as a dangerous } \\
\text { communicable disease }\end{array}$ & $\begin{array}{l}\text { Ministry of Public Health announced COVID-19 as a dangerous } \\
\text { communicable disease by the Communicable Diseases Act, B.E. } 2558 \\
\text { (A.D. 2015) }\end{array}$ \\
\hline & March 1 & 10 & First fatal case & The first fatal case, in a patient who had an underlying disease \\
\hline & March 3 & 10 & Group from South Korea & Thai workers returned from South Korea \\
\hline & March 9 & 10 & $\begin{array}{l}\text { Entertainment venues } \\
\text { cluster }\end{array}$ & Confirmed cases from entertainment venues \\
\hline & March 11 & 11 & Boxing stadium cluster & Confirmed cases from entertainment venues \\
\hline & March 15 & 12 & $\begin{array}{l}\text { Group from Dakwah } \\
\text { Pilgrimage }\end{array}$ & 132 Thai nationals from Dakwah Pilgrimage \\
\hline & March 16 & 12 & New Year revocation & Thai New Year (Songkran festival) on April 13-15 canceled \\
\hline & March 18 & 12 & Social distance & Social distancing measures initiated \\
\hline & March 21 & 12 & $\begin{array}{l}\text { Schools and universities } \\
\text { closure }\end{array}$ & \\
\hline \multirow{7}{*}{ 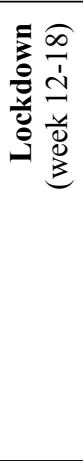 } & March 22 & 12 & Bangkok lockdown & Bangkok Governor announces lockdown measures \\
\hline & March 26 & 13 & $\begin{array}{l}\text { Thailand emergency } \\
\text { decree }\end{array}$ & Emergency decree included the closure of borders \\
\hline & March 26 & 13 & Inception of the CCSA & $\begin{array}{l}\text { Thai Government establishes the Center for COVID-19 Situation } \\
\text { Administration (CCSA) }\end{array}$ \\
\hline & April 3 & 14 & Nationwide curfew & $\begin{array}{l}\text { Nationwide curfew }(22: 00-04: 00) \text { for all except medical personnel, law } \\
\text { enforcement, logistics workers, or those who have a necessary reason } \\
\text { to be out at that time }\end{array}$ \\
\hline & April 4 & 14 & $\begin{array}{l}\text { Enforcement of state } \\
\text { quarantine }\end{array}$ & $\begin{array}{l}\text { Enforcement of state quarantine to all arriving international flight } \\
\text { without exception }\end{array}$ \\
\hline & April 12 & 16 & $\begin{array}{l}\text { Alcoholic beverage trade } \\
\text { prohibition }\end{array}$ & \\
\hline & $\begin{array}{l}\text { April 13- } \\
15\end{array}$ & 16 & $\begin{array}{l}\text { New Year celebration } \\
\text { canceled }\end{array}$ & \\
\hline \multirow{7}{*}{ 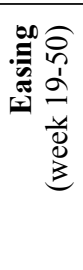 } & May 3 & 19 & First phase easing & \\
\hline & May 17 & 21 & Second phase easing & \\
\hline & June 1 & 23 & Third phase easing & \\
\hline & June 15 & 25 & Fourth phase easing & \\
\hline & July 1 & 27 & Fifth phase easing & \\
\hline & July $25-28$ & 31 & $1^{\text {st }}$ New Year rescheduling & $1^{\text {st }}$ Thai New Year rescheduling on July $25-28,2020$ \\
\hline & $\begin{array}{l}\text { September } \\
4-7\end{array}$ & 36 & $2^{\text {nd }}$ New Year rescheduling & $2^{\text {nd }}$ Thai New Year rescheduling on Sep 4-7, 2020 \\
\hline \multirow{4}{*}{ 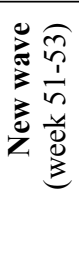 } & $\begin{array}{l}\text { December } \\
18\end{array}$ & 51 & $\begin{array}{l}\text { The first case related to the } \\
\text { Central Shrimp Market }\end{array}$ & The first case in the shrimp market cluster \\
\hline & $\begin{array}{l}\text { December } \\
19\end{array}$ & 51 & Samut Sakhon lockdown & $\begin{array}{l}\text { Thai DDC announce lockdown measures with a curfew }(22: 00-05: 00) \\
\text { including travel restriction only for foreign workers }\end{array}$ \\
\hline & $\begin{array}{l}\text { December } \\
24\end{array}$ & 52 & $\begin{array}{l}\text { The first case in an illegal } \\
\text { gambling den cluster }\end{array}$ & The first case in an illegal gambling den cluster \\
\hline & $\begin{array}{l}\text { December } \\
24\end{array}$ & 52 & Zone classification & $\begin{array}{l}\text { Zone classification by colors (red, orange, yellow, and green), } \\
\text { depending on the local situation }\end{array}$ \\
\hline
\end{tabular}

2 


\section{Table 2 (on next page)}

Impact of COVID-19 pandemic on other viral infections in Thailand, 2019-2020.

*Percentage of positive cases from all specimens. †Viral infection data were obtained from clinical data from the hospital in Bangkok (Suntronwong et al., 2020). §Dengue data were from Report 506, Thai DDC (Bureau of Epidemiology, 2021). 
1 Table 2. Impact of COVID-19 pandemic on other viral infections in Thailand, 2019-2020.

\begin{tabular}{|c|c|c|c|c|c|c|}
\hline & & \multicolumn{3}{|c|}{$\mathrm{n}(\%)^{*}$} & \multicolumn{2}{|c|}{ Trend (per week) } \\
\hline & & 2019 & 2020 & $p$ value & 2019 & 2020 \\
\hline Influenza $\dagger$ & Total & $1,230(25.8)$ & $303(12.3)$ & $<0.001$ & -0.1415 & -0.4884 \\
\hline & Before lockdown & $377(33.7)$ & $287(22.2)$ & 0.29 & 1.927 & -3.318 \\
\hline & Lockdown & $182(77.1)$ & $0(0.0)$ & 0.001 & -1.357 & 0.0 \\
\hline & Easing & $621(61.9)$ & $10(0.4)$ & $<0.001$ & 0.838 & 0.04032 \\
\hline & New wave & $50(49.0)$ & $6(2.9)$ & 0.07 & -5.000 & 0.0 \\
\hline \multirow[t]{5}{*}{$\mathrm{RSV \dagger}$} & Total & $171(3.6)$ & $297(12.1)$ & 0.17 & 0.1035 & 0.3743 \\
\hline & Before lockdown & $12(0.9)$ & $8(0.7)$ & 0.39 & 0.009091 & -0.2000 \\
\hline & Lockdown & $6(1.2)$ & $1(0.4)$ & 0.03 & 0.1429 & -0.07143 \\
\hline & Easing & $147(5.4)$ & $256(9.3)$ & 0.14 & 0.1292 & 0.9479 \\
\hline & New wave & $6(2.9)$ & $14(6.8)$ & 0.47 & -1.000 & -5.000 \\
\hline \multirow[t]{5}{*}{ Rotavirus $\dagger$} & Total & $25(6.0)$ & $164(37.3)$ & $<0.001$ & -0.01895 & -0.2857 \\
\hline & Before lockdown & $15(12.3)$ & $158(39.2)$ & $<0.001$ & -0.4909 & -1.336 \\
\hline & Lockdown & $1(1.2)$ & $6(17.6)$ & 0.27 & 0.03571 & -0.2143 \\
\hline & Easing & $3(1.6)$ & $0(0.0)$ & 0.08 & -0.01118 & 0.0 \\
\hline & New wave & $6(30.0)$ & $0(0.0)$ & 0.12 & 1.500 & 0.0 \\
\hline \multirow[t]{5}{*}{ Norovirus $\dagger$} & Total & $138(14.2)$ & $59(10.3)$ & 0.01 & 0.07273 & -0.09539 \\
\hline & Before lockdown & $28(23.0)$ & $53(13.0)$ & 0.17 & -0.4182 & -0.5091 \\
\hline & Lockdown & $4(4.7)$ & $3(8.1)$ & 0.79 & -0.3214 & 0.1071 \\
\hline & Easing & 79 (11.9) & $3(2.3)$ & $<0.001$ & 0.1219 & -0.001283 \\
\hline & New wave & $27(26.7)$ & $0(0.0)$ & 0.049 & -3.500 & 0.0 \\
\hline \multirow[t]{5}{*}{ Dengue $\S$} & Total & 131,157 & 71,292 & $<0.001$ & 35.86 & 12.35 \\
\hline & Before lockdown & 12,545 & 7,134 & $<0.001$ & 39.41 & 1.391 \\
\hline & Lockdown & 8,188 & 4,804 & 0.001 & 55.36 & 86.61 \\
\hline & Easing & 105,975 & 58,883 & $<0.001$ & -38.86 & -50.98 \\
\hline & New wave & 4,449 & 471 & 0.14 & 250.0 & -307.0 \\
\hline
\end{tabular}

2 *Percentage of positive cases from all specimens. $\dagger$ Viral infection data were obtained from

3 clinical data from the hospital in Bangkok (Suntronwong et al., 2020). §Dengue data were from

4 Report 506, Thai DDC (Bureau of Epidemiology, 2021). 


\section{Table 3 (on next page)}

Impact of the COVID-19 Pandemic on the Outpatient Department (OPD) in KCMH, 2019 and 2020.

$\mathrm{n}=$ number of outpatient clinic visits in $\mathrm{KCMH}$. 
1 Table 3. Impact of the COVID-19 Pandemic on the Outpatient Department (OPD) in

2 KCMH, 2019 and 2020.

\begin{tabular}{|c|c|c|c|c|c|c|}
\hline & & \multicolumn{3}{|c|}{$\mathrm{n}$} & \multicolumn{2}{|c|}{ Trend (per week) } \\
\hline & & 2019 & 2020 & $p$ value & 2019 & 2020 \\
\hline OPD service & Total & $1,389,783$ & $1,327,606$ & 0.29 & 16.81 & 55.88 \\
\hline & Before lockdown & 283,013 & 300,562 & 0.52 & 651.3 & 819.8 \\
\hline & Lockdown & 176,443 & 136,424 & 0.09 & 35.64 & -1440.0 \\
\hline & Easing & 868,961 & 812,904 & 0.10 & 64.50 & 208.1 \\
\hline & New wave & 61,366 & 77,716 & 0.66 & -15429.0 & -7704.0 \\
\hline
\end{tabular}

$3 \mathrm{n}=$ number of outpatient clinic visits in $\mathrm{KCMH}$.

4 


\section{Table 4 (on next page)}

Attempt to suicide and Suicide, 2019-2020.

$\mathrm{n}=$ number of cases reported to the Department of Mental Health. 
1 Table 4. Attempt to suicide and Suicide, 2019-2020.

\begin{tabular}{|c|c|c|c|c|c|c|}
\hline & & \multicolumn{3}{|c|}{$\mathrm{n}$} & \multicolumn{2}{|c|}{ Trend (per week) } \\
\hline & & 2019 & 2020 & $p$ value & 2019 & 2020 \\
\hline \multirow[t]{5}{*}{ Attempt to suicides } & Total & 8,098 & 10,006 & 0.001 & 2.331 & -2.329 \\
\hline & Before lockdown & 1,418 & 2,651 & $<0.001$ & 1.100 & 3.318 \\
\hline & Lockdown & 896 & 1,381 & $<0.001$ & -2.643 & -4.750 \\
\hline & Easing & 5,230 & 5,661 & 0.35 & 6.049 & -2.599 \\
\hline & New wave & 554 & 313 & 0.24 & -91.50 & -35.00 \\
\hline \multirow[t]{5}{*}{ Suicides } & Total & 2,520 & 4,022 & $<0.001$ & 1.042 & -1.145 \\
\hline & Before lockdown & 408 & 1,072 & $<0.001$ & 0.1636 & 1.009 \\
\hline & Lockdown & 245 & 629 & $<0.001$ & -0.8214 & -2.536 \\
\hline & Easing & 1,653 & 2,189 & $<0.01$ & 2.476 & -1.420 \\
\hline & New wave & 214 & 132 & 0.25 & -31.50 & -10.00 \\
\hline
\end{tabular}

$2 \mathrm{n}=$ number of cases reported to the Department of Mental Health.

3 


\section{Table 5 (on next page)}

Pandemic Impact on Traffic Indicators, 2019-2020.

$\mathrm{n}=$ number of cases reported to the Ministry of Transport 
1 Table 5. Pandemic Impact on Traffic Indicators, 2019-2020.

\begin{tabular}{|c|c|c|c|c|c|c|}
\hline & & \multicolumn{3}{|c|}{$\mathrm{n}$} & \multicolumn{2}{|c|}{ Trend (per week) } \\
\hline & & 2019 & 2020 & $p$ value & 2019 & 2020 \\
\hline \multirow[t]{5}{*}{ Road accidents } & Total & 19,575 & 21,587 & 0.17 & 0.2000 & 1.998 \\
\hline & Before lockdown & 4,006 & 4,607 & 0.14 & -14.09 & -3.309 \\
\hline & Lockdown & 3,560 & 2,356 & 0.17 & 15.18 & -5.571 \\
\hline & Easing & 9,931 & 12,840 & $<0.001$ & 1.264 & 3.269 \\
\hline & New wave & 2,078 & 1,784 & 0.73 & 285.5 & 251.5 \\
\hline \multirow{5}{*}{$\begin{array}{lll}\begin{array}{l}\text { Injuries } \\
\text { accidents }\end{array} & \text { from } & \text { road } \\
\end{array}$} & Total & 16,605 & 16,585 & 0.99 & 0.2272 & 1.592 \\
\hline & Before lockdown & 3,287 & 3,934 & 0.21 & -15.55 & -11.55 \\
\hline & Lockdown & 3,396 & 1,578 & 0.08 & 21.07 & -5.679 \\
\hline & Easing & 7,821 & 9,455 & 0.02 & 0.6420 & 3.987 \\
\hline & New wave & 2,101 & 1,618 & 0.63 & 392.0 & 239.0 \\
\hline \multirow{5}{*}{$\begin{array}{lll}\begin{array}{l}\text { Fatalities } \\
\text { accidents }\end{array} & \text { from } & \text { road } \\
\end{array}$} & Total & 2,862 & 3,137 & 0.24 & 0.1719 & 0.3070 \\
\hline & Before lockdown & 578 & 715 & 0.03 & -3.191 & -0.2273 \\
\hline & Lockdown & 537 & 304 & 0.10 & 3.786 & -1.893 \\
\hline & Easing & 1,464 & 1,846 & $<0.001$ & 1.058 & 0.6620 \\
\hline & New wave & 283 & 272 & 0.93 & 9.000 & 49.00 \\
\hline
\end{tabular}

2

$3 n=$ number of cases reported to the Ministry of Transport 
Figure 1

The Covid-19 outbreak in Thailand and related events. 


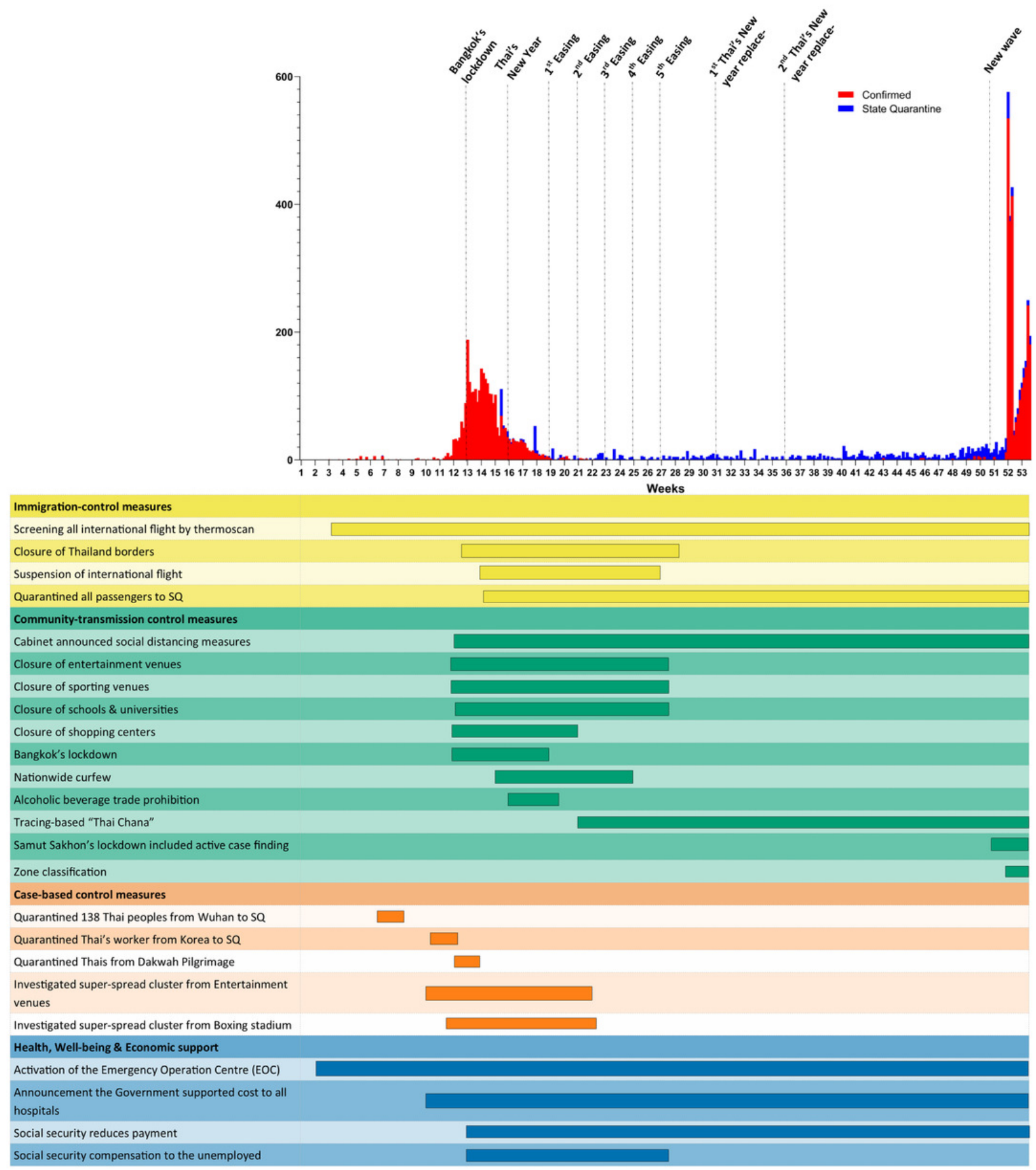


Figure 2

Relationship of COVID-19 cases to other viral diseases, 2019-2020.

a) influenza, b) respiratory syncytial virus (RSV), c) rotavirus, d) norovirus, and e) dengue. 

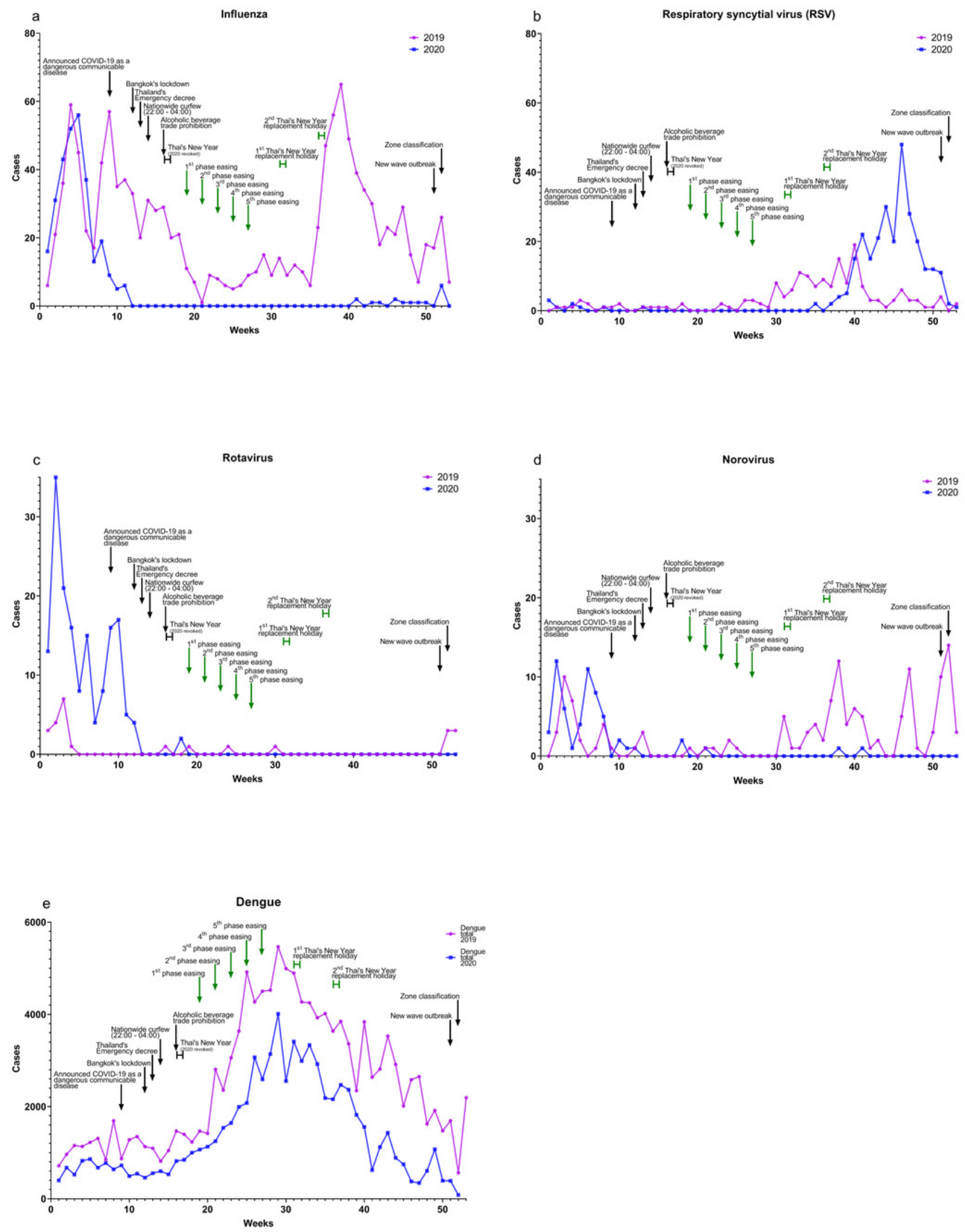
Figure 3

Patients Visits to the OPD in the KCMH, 2019 and 2020.

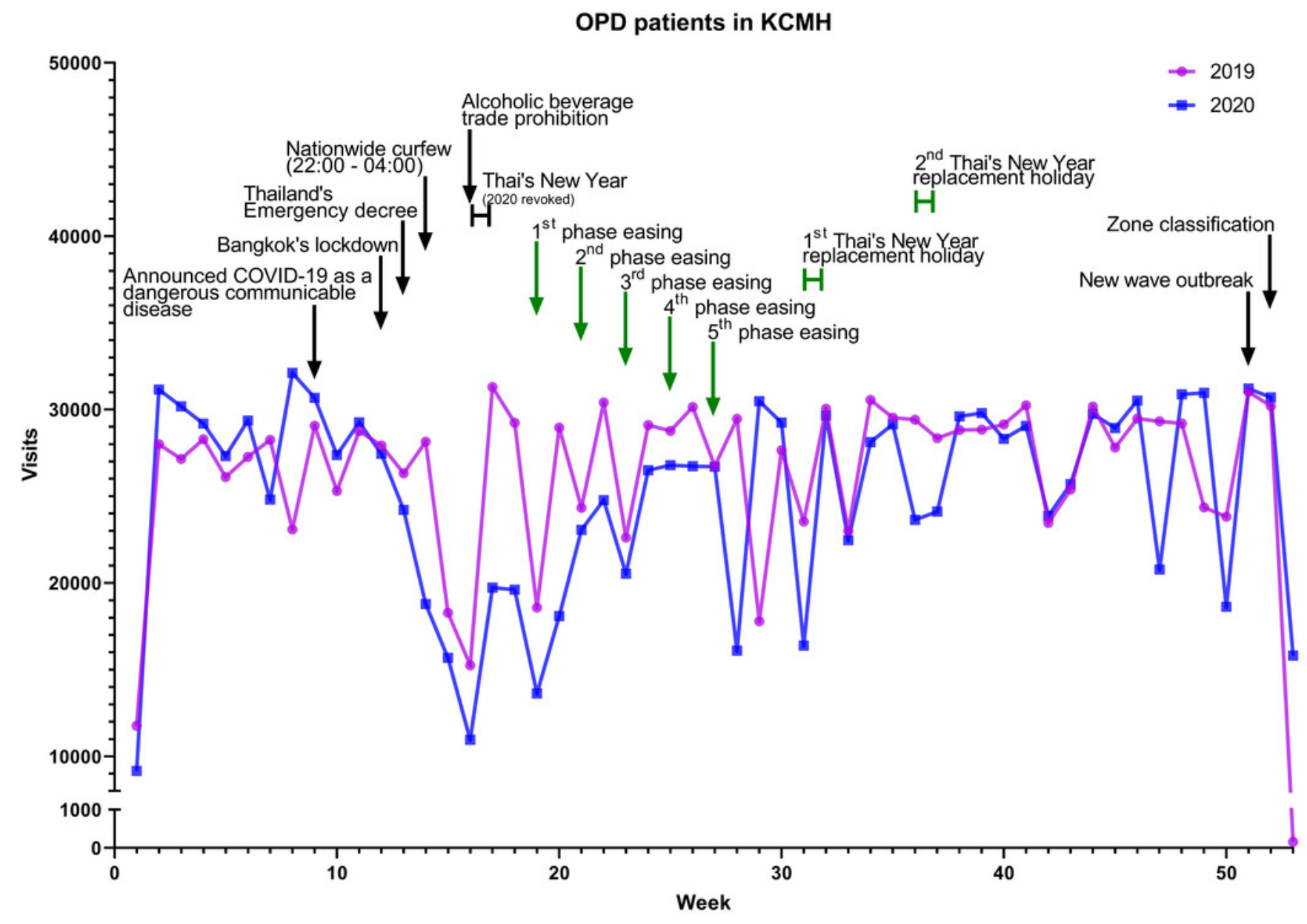


Figure 4

Suicidal behavior.

Data from the self-harm surveillance system (Report 506S), Thai Department of Mental Health (Department of Mental Health, 2021), shows both a) attempt to suicide and b) suicide.
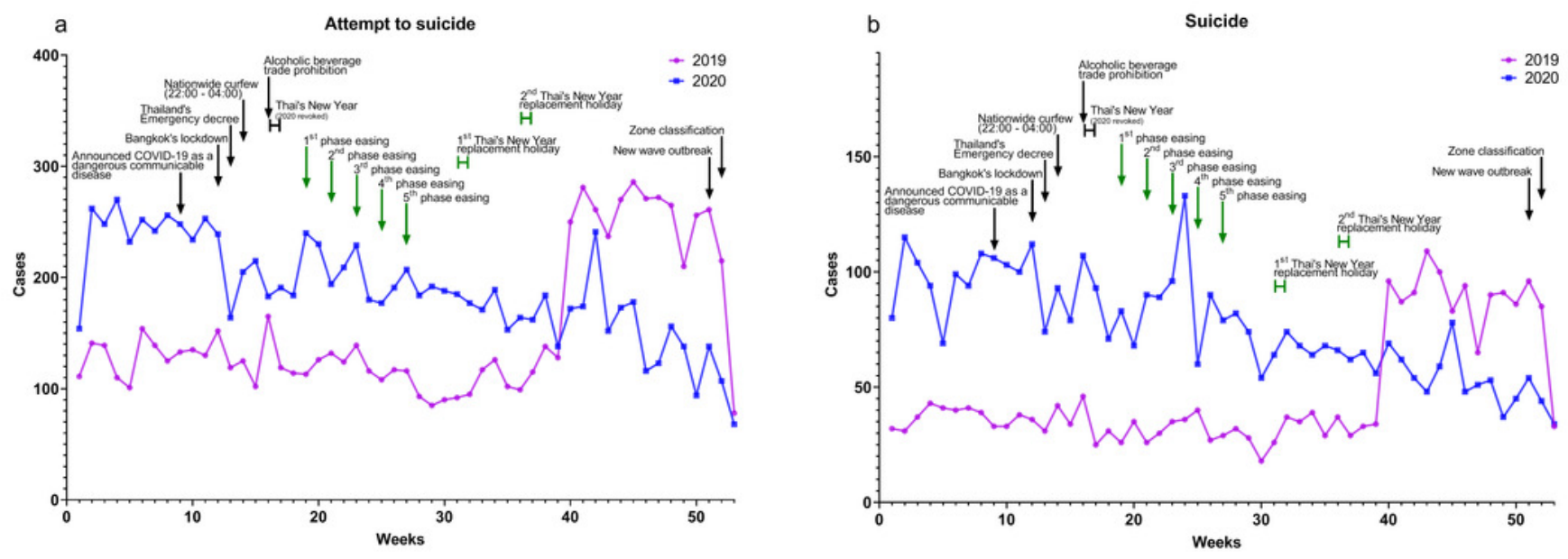
Figure 5

Road accident incidences and fatalities, 2019-2020.

Data from TRAMS report system, the Thai Ministry of Transport (Ministry of Transport, Thailand, 2021) a) road accidents b) injuries from road accidents, and c) fatalities from road accidents
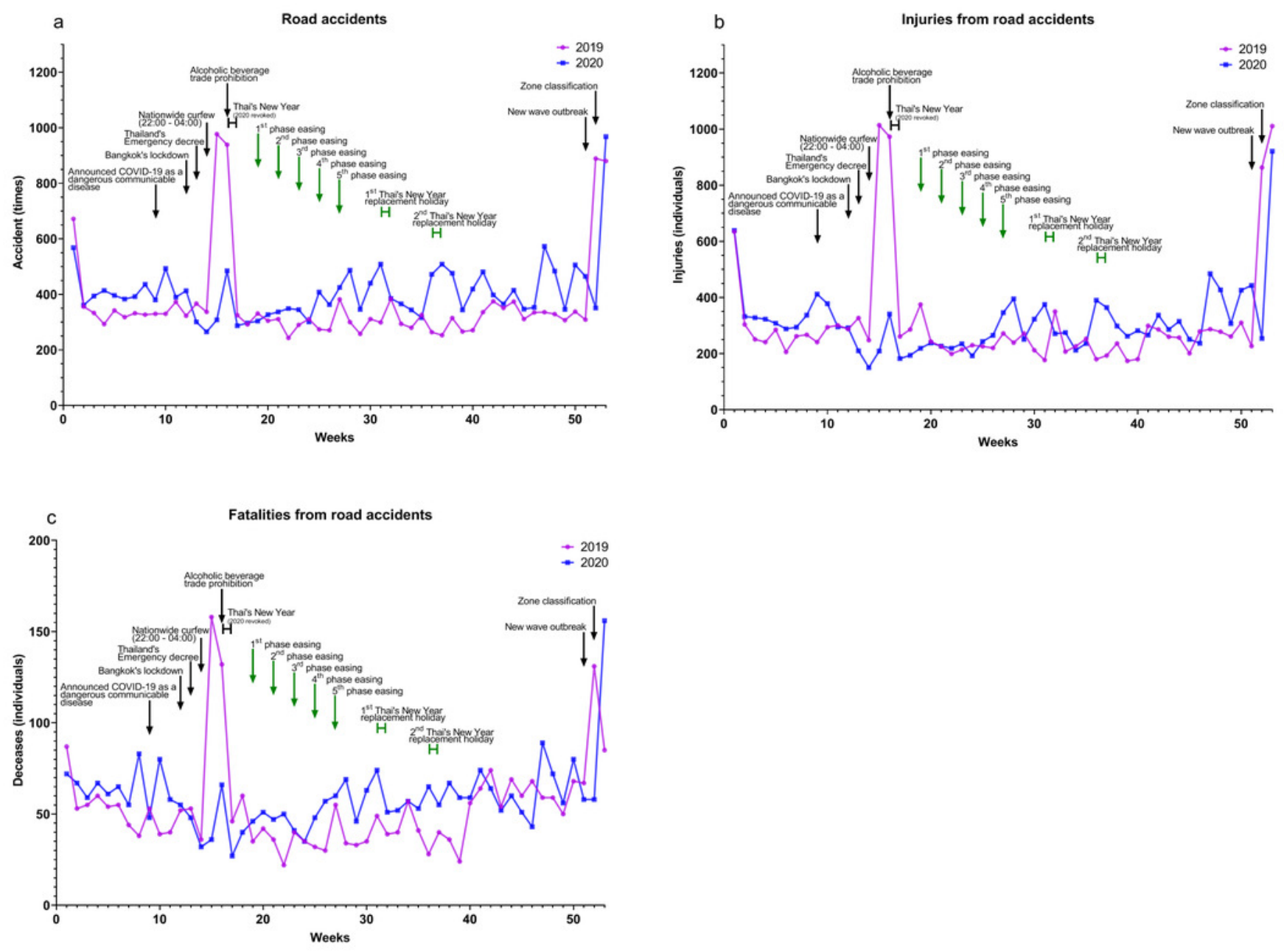